\title{
Playing with Fire: Narrating Angry Women and Men in the Heptaméron
}

\author{
EMILY E. THOMPSON
}

Webster University

In De Ira, Seneca dedicates three books to the denunciation of anger, a passion he insists serves no necessary purpose and leads to countless ills. Certainly Marguerite de Navarre acknowledges the violent potential of this passion in the stories of the Heptaméron. Yet her devisants not only justify some forms of anger in the stories they tell, they also freely give expression to their own anger during the ensuing discussions. The historian Natalie Zemon Davis even cites the Heptaméron as an example of a literary text that allows sixteenth century readers to imagine a menacing, yet justifiable female anger. A systematic study of references to anger in the Heptaméron indeed reveals a gendered revision of Seneca's and Aristotle's ideas on anger. Women with a distinctly feminine honour to defend take their place beside angry male warriors. And women are depicted as capable both of expressing anger and of controlling it. Marguerite's choice of words, her sequencings of stories, and the arguments she expresses through her devisants suggest ways in which anger can be useful to both sexes. A necessary outlet for intense feeling, a controlled anger can balance a sense of noble self-affirmation with the self-abnegation required for social harmony and Christian salvation.

Avec son De Ira, Sénèque consacre trois livres à la dénonciation de la colère, une passion qui, selon lui, entraîne tous les maux sans avoir une seule fonction utile. Au seizième siècle, Marguerite de Navarre reconnait le danger de cette passion et illustre son potentiel violent dans son Heptaméron. Néanmoins, les "devisants" qui racontent ces nouvelles justifient parfois des cas de colère, et ne se privent pas d'exprimer leur propre colère lors des discussions qui suivent chaque nouvelle. L'historienne Natalie Zemon Davis va jusqu’à prétendre qu'avec l'Heptaméron, Marguerite permet aux lecteurs du seizième siècle de concevoir une colère féminine, à la fois acceptable et menaçante. Une étude exhaustive des références à la colère dans l'Heptaméron, révèle effectivement une révision féminine des idées de Sénèque et d'Aristote portant sur la colère. À côté des soldats furieux, Marguerite met en scène des femmes prêtes à défendre un honneur féminin. Ces femmes se montrent capables non seulement de ressentir la colère mais aussi de la contrôler. Avec un lexique particulier, des regroupements thématiques des nouvelles et les opinions quelle fait circuler parmi ses "devisants", Marguerite évoque une utilité, quoique limitée, de la colère. Son recueil de nouvelles donne le jour à une colère qui soulage d'autres passions nocives et tente d'équilibrer, d'une part, une affirmation du moi noble, et de l'autre, une dénégation du soi requise par l'Église et par la vie commune.

\section{A woman infuriated with her unfaithful husband sets fire to the straw upon which he lies with his mistress. Such a situation would have provided compelling material for a misogynist author of the sixteenth century who}


wished to convince readers of women's dangerous lack of emotional restraint. Surprisingly, however, this constitutes the plot of tale 37 of the Heptaméron, a story chosen by the devisant Dagoucin in order to praise women and provide an example of marital stability. How should we interpret the story today? Is Marguerite de Navarre championing female rage? Is Dagoucin mocking the female devisants? Or do the story and its frame illustrate the insidious power of a narrator to adapt any tale to a hidden agenda?

As Linda Pollock reminds us, early modern aristocrats had inherited a dizzyingly rich and contradictory set of precepts concerning anger and, although none of them promoted a positive form of feminine anger, early modern women did express anger in ways that were sometimes acceptable to their peers. ${ }^{1}$ Although sixteenth-century women as well as men displayed anger publicly, social norms put the burden on women to defend their wrath as just. ${ }^{2}$ In Fiction in the Archives: Pardon Tales and Their Tellers in SixteenthCentury France, Natalie Zemon Davis illustrates how making a case for a justifiable woman's anger required the complexity of a skilled storyteller. She goes on to argue that Marguerite was one such storyteller, citing tales 36 and 37 where multiple perspectives on anger make it possible to conceive of a socially justifiable type of anger expressed by women. ${ }^{3}$

The rapprochement of the Heptaméron with pardon tales from the archives is compelling; the stories of the Heptaméron certainly suggest Marguerite's interest in questions of justice. But as Davis herself wonders, would the murderous, often common, women of the pardon tales have moved the author of the Heptaméron?4 Davis concentrates in particular on anger that leads to violence. Using a more systematic analysis of the Heptaméron, I will examine Marguerite's treatment of a range of types of anger displayed by women and will identify the sociallydetermined limitations she imposes on the expression of this particular passion. Throughout, I will consider the psychological and social implications gleaned from the Heptaméron as part of a distinctly literary construction.

1. Linda A. Pollock, "Anger and the Negotiation of Relationships in Early Modern England," The Historical Journal 47. 3 (2004): 569-70 and 576-82.

2. Gwynne Kennedy, Just Anger: Representing Women's Anger in Early Modern England (Edwardsville: Southern Illinois University Press, 2000), 12.

3. Natalie Zemon Davis, Fiction in the Archives: Pardon Tales and their Tellers in Sixteenth-Century France (Stanford: Stanford University Press, 1987), 108-10.

4. Davis, 107. 
One thing is undeniable: the Heptaméron is a text overflowing with anger. Concordances of the Heptaméron reveal forty-nine out of seventytwo stories containing at least one example from a lexicon of anger ${ }^{5}$ (forms of colère, courroux, fureur, ire, dépit, or the verb enrager). ${ }^{6}$ All but two of the stories from day one revolve around anger, and this day of storytelling culminates in tale 10 about Amadour and Floride, a tale that virtually explodes with manifestations of the emotion. From valets to queens, everyone in the Heptaméron is shown to be susceptible to anger.

While women regularly display anger in Marguerite's fiction, the medical treatises of her time continued to explain anger in mostly humoral terms that rendered female anger suspect. ${ }^{7}$ In men, anger was seen as an intensifier of warlike qualities like aggression and courage that male bodies with their hot and dry humours were designed to experience. When male anger bypassed normal limits and led to inappropriate violence, Galenist theories could come to the defense of the male aggressor. Women, on the other hand, were believed incapable of healthy, warlike anger because of their inferior humoral balance (wet and cold). Women's anger was instead imputed to a general female weakness. Whereas an infuriated man could be seen as having taken the admirable quality of virility to an extreme, an infuriated woman was either an aberration-a virile-like aggressor-or confirmation of women's innate vulnerability to passions.

One might thus expect Marguerite to avoid a physiological depiction of anger if her intention was to evoke an acceptable, female expression of this emotion. On the contrary, she details the physical manifestations of anger in several tales, drawing the reader's attention, for example, to the ways in which anger deforms Amadour's appearance: "son visaige et ses yeulx tant alterez que le plus beau taint du monde estoit rouge comme feu, et le plus doulx et plaisant

5. As Alessandro Arcangeli reminds us, careful consideration of the specific words used to evoke passions in early modern texts can help modern critics avoid anachronistic psychological analyses. See "Écrits sur la colère et système des passions au XVIe siècle," L'Atelier du Centre de recherches historiques 11 (2013): 1-17.

6. Suzanne Hanon, Le Vocabulaire de l" "Heptaméron » de Marguerite de Navarre : Index et concordance (Paris: Champion-Slatkine, 1990) and Guy Demerson and Gilles Proust, L'Heptaméron: Index (Clermont-Ferrand: Presses universitaires Blaise Pascal, 2005).

7. Ian Maclean, The Renaissance Notion of Woman: A Study in the Fortunes of Scholasticism and Medical Science in European Intellectual Life (Cambridge: Cambridge University Press, 1980), 46. 
regard sy horrible et furieux qu'il sembloit que ung feu tresardent estincelast dans son cueur et son visaige." ${ }^{8}$ Describing the physical effects of anger in terms of fire reinforces the connection to the dry, hot humour that choler was understood to be. In another example, Marguerite explicitly adopts a humoral explanation for the anger that cures a sick woman: "la collere consomma l'humiditié du caterre qui la gardoit de parler en sorte quelle leur dist toutes les injures dont elle se peut adviser. Et, depuis ceste heure là, commança de guerir" (503). Marguerite does not shy away from using the term colère, etymologically recalling the choler primarily associated with male bodies. Furthermore, she reinforces the causality between choler and masculine aggressivity. The furious Amadour, like the furious duke from tale 70, unleashes his anger first on his beloved but later on the battlefield where his unbridled emotions find more honourable outlets. In other tales, too, Marguerite appears to designate rage as an excess of maleness and to contrast it with the behaviour expected from women: "Tout ainsi que ung bon gendarme, quant il veoit son sang, est plus eschauffé à se venger de ses ennemys et acquerir l'honneur, ainsi son chaste cueur [à la muletiere d'Amboise] se renforça doublement à courir et fuyr des mains de ce malheureux [...]" (23). The devisants also seem to subscribe to this humoral view of anger when Parlamente says of Camelle:9 "celles qui sont vaincues du plaisir ne se doibvent plus nommer femmes, mais hommes, desquelz la fureur et la concupiscence augmente leur honneur" (365) or when Oisille describes the passionate duchess from tale 70 as having assumed "le cueur d'un homme transporté" (478)..$^{10}$

Although Oisille here conflates the duchess's behaviour with the male body, her use of the "coeur d'un homme" remains metaphorical, something the duchess can assume during her rage. And the duchess's supposedly masculine wrath and lust share the same body with other negative traits commonly attributed to a woman's nature: deception, jealousy, vanity, and infidelity, not to mention excessive weeping. She therefore makes a very poor model for

8. Marguerite de Navarre, Heptaméron, ed. Renja Salminen (Geneva: Droz, 1999), 96. Hereafter cited in parentheses in the text.

9. The protagonist of tale 43 , known as Jambique in other editions.

10. Although seemingly predicated on the inferiority of the colder, wetter female body, humoral theories were no longer necessarily incompatible with a proto-feminist perspective. For more on sixteenthcentury reinterpretations of Galen and Aristotle that surprisingly champion a type of sexual equality, see Maclean, 28-46. 
the physiological argument, revealing extreme traits of both male and female bodies. In the case of the condemnation of Camelle as overly masculine, the focus is on her surrender to rage and the acts she then chooses to commit, not on the initial experience of anger. Both the tale that precedes tale 43 and the one that follows it evoke honourable yet angry women who do not act upon their anger and who are therefore not criticized by the devisants.

More significantly, Marguerite problematizes a straightforward humoral explanation of anger by writing tales where men's rage, far from expressing their virile courage, instead covers up their cowardice. An example of this is Parlamente's sarcastic commentary on Amadour's mad attack on Floride which quickly subsides when Floride's mother comes to her rescue: "Amadour, qui n'etoit pas sy prest à mourir qu'il disoit, laissa de sy bonne heure son entreprise" (98). The coupling of fury and cowardice occurs often enough in the Heptaméron for Parlamente later to draw this conclusion: "tout homme furieux est tousjours peureux" (295). Marguerite suggests, in fact, that the theory of an honourable, bile-induced rage, far from explaining men's uncontrollable anger, serves as an excuse for inappropriate excesses. When Saffredent attempts to dodge responsibility for seducing women by citing "fureur," the female devisants are not duped (322). Male characters within the individual tales of the Heptaméron likewise make deliberate use of a so-called "natural" fury in their strategies of seduction. But the adjective "fainct" denounces their hypocritical and calculated abandonment of reason and further undermines a humoral explanation of anger. ${ }^{11}$ Like Seneca, then, Marguerite stresses the consciousness of all acts inspired by anger. Where the mind must acquiesce, restraint is possible.

Finally, the sheer number of socially integrated, respectable women expressing anger in the Heptaméron-among them Parlamente, Ennasuitte, and Nomerfide-invalidates a simple equation of anger with male bodies. Long before the humoral theory had been discredited in medical circles, then, Marguerite presents both men and women capable of regularly expressing and controlling anger. By representing men as exploiting anger as an excuse for socially inappropriate behaviour, she actually reverses the common physiological association of negative forms of anger with women and admirable ones with men and forces the reader to accept her angry female characters 
as something other than natural oddities or emotionally weak. All the same, there are male characters in the Heptaméron who demonstrate the capacity for a less hypocritical, more controlled form of anger, just as some female characters succumb to violent rage. In order to distinguish between acceptable and unacceptable expressions of anger, readers are forced to reject corporeal categories and turn instead to social ones.

Indeed, the devisants situate the triggers, extenuating circumstances, and controls for anger firmly within a social context in the Heptaméron. ${ }^{12}$ Although some of the terms Marguerite favours when naming this particular passion derive etymologically from physiological concepts of anger (colère, fureur), she uses them to form a distinctly social classification of anger that suggests at once a range and a progression of stages in the emotion whose steps are also determined by social factors. The most frequently used terms are forms of dépit, colère, courroux, and fureur. ${ }^{13}$ Dépit tends to refer to a more internally experienced anger with corrosive potential. Colère implies an external manifestation, but usually a mild and common form of anger, sometimes qualified with expressions like "un peu" or "et demie en riant." The forms of the verb courroucer highlight anger that inspires action. Finally, fureur evokes the most intense expressions of anger, accompanied by acts of violence and described as resistant to reason and to social safeguards. This lexical categorization is, above all, a literary one, of course, and therefore provides not so much a precise, scientific classification as a guide to deciphering anger in the Heptaméron. Discernible patterns in the choice of terms used to evoke anger prepare the reader to interpret anger in either a more favourable or a more critical way.

Perceived slights are the most common triggers for anger of all levels of intensity in the Heptaméron. Just as sixteenth-century honour relied on public recognition, acts of disrespect were often made in a public way too. In tale 21, when Rolandine fails to respect her authority in their public confrontation, the queen is enraged: "en continuant de la reprandre et injurier par collere, se print à pleurer, en disant : 'Malheureuse que vous estes, en lieu de vous humilier devant

12. For analyses of the social factors that contributed to distinctions between just anger and sinful anger in medieval contexts, see Anger's Past: the Social Uses of an Emotion in the Middle Ages, ed. Barbara H. Rosenwein (Ithaca: Cornell University Press, 1998).

13. Hanon's concordance and Demerson and Proust's index show, in various grammatical forms and with varying spellings, thirty-five examples of dépit, thirty-five of fureur, forty-five of colère, and fortytwo of courroux. Enrager and ire appear eight and three times respectively. 
moy, et de vous repentir d'une faulte sy grande, vous parlez audacieusement'" (209-10). Other characters in the Heptaméron feel dishonoured when the infidelity of their spouse becomes common knowledge, for example in tales 3 , 32,37 . Characters suffering from hurt pride sometimes see unrequited passion as a dishonour to be revenged, but since their suffering tends to be provoked by a private humiliation, the devisants are less forgiving of their anger. ${ }^{14}$

Although modern scholars associate honour primarily with the dominant group in sixteenth-century society-noblemen-a sense of honour and entitlement was not unique to them. Women as well as men, lesser nobles ${ }^{15}$ as well as non-nobles, attributed importance to their reputations and to the public acknowledgment of certain rights. It is nonetheless true that the noble devisants take slights to a character's honour more seriously if that character is part of the elite. There is a single, unambiguous example of legitimate, non-noble anger in the Heptaméron. Françoise in tale 42 admits herself that she is exceptional, but the validity of her position is not questioned by the devisants: "elle navoit le cueur moings honneste que la plus grand princesse de chrestienté, et n'estimoit tresor au monde au pris de l'honneur et de la conscience" (350). Similarly, the devisants seem to concede that women also need a means of redress when their honour has been attacked, although the male devisants are much more likely to forgive men acting to revenge their masculine honour than to forgive women angrily defending their own. A similar gendered partiality is true of the female devisants when judging the angry responses of humiliated women. Although there is disagreement along gender lines and a bias towards the elite, overall, the devisants find the desire for revenge legitimate and are highly sympathetic to characters who experience anger as a result of a loss of honour. When Longarine tells of a mistreated wife who shows no anger, Parlemente dismisses the woman, bourgeoise though she may be, as someone "sans cuer sans fiel ne sans foye" (330).

Neither the characters the devisants evoke nor the devisants themselves follow Seneca's advice to suppress anger. Those who acknowledge a moderate anger (colère) and allow it to surface suffer fewer negative consequences than those who try to hide their displeasure (dépit). A noblewoman in tale 15 admonishes a husband who neglects his young, subservient wife for fear that 
"par despit, elle face ce que, estant bien traictée, n'ouseroit jamais penser" (145). And, indeed, like the Queen of Naples in tale 3, the young wife's suppressed anger finds an outlet later in adultery. Men, too, are corrupted by dépit, like the prior in tale 22 who cannot openly express the anger he feels when his illicit advances are rejected. Instead, consumed by "ung merveilleux despit" (225), he proceeds to abandon his principles before eventually dying of shame.

Openly expressing anger, however, risks the opposite effect-projecting violence outwards in a form of revenge. Marguerite even depicts herself in the tale mentioned above, so indignant that she feels an "envie de venger l'innocence de ceste pouvre fille" (227). Marguerite's devisants are clearly not shocked by the principle of revenge, which they often judge useful for deterring asocial behaviour and punishing infringements of the social code. In this way they are representative of their era. ${ }^{16}$ Indeed, the majority of angry men and women in the Heptaméron contemplate revenge against a perceived enemy. It is when that revenge is enacted that a distinction is made between exemplary characters and culpable ones. When characters act impulsively and against social custom, they are condemned. The nobleman in tale 40 , for example, finds his sister in bed with his serviteur and immediately acts on his rage; "oultré de courroux" (336), he orders his servants to kill his former companion. In the ensuing discussion, the devisants focus primarily on the plight of the sister, unable to make sense of the brother's violent deed. Even some of the male devisants condemn him for his cruelty. The narrator, Parlemente, concludes with a rare moralizing tone when she presents the ruin of the house as punishment for the murder committed by the brother. Tale 16, in contrast, introduces a spurned lover who more judiciously transforms his anger into actions that ultimately reward him and do not threaten family cohesion. The devisants take the man's anger for granted: "[s]i le gentilhomme fut courroucé de ceste parolle, ceulx qui ont experimenté choses semblables diront bien que ouy" (161). Here, again, they focus not on the emotion but on the specific actions it inspires in debating whether or not a character provides a positive, moral model.

The punishment must fit the crime; too violent a revenge becomes socially disruptive, threatening the sense of community and even recalling non-human violence: "tout ainsi que ung sanglier, lequel, estant navré d’un 
espieu, court d'impetuosité contre celluy qui a faict le coup" (496). When anger leads to a physical punishment judged excessive, Marguerite invariably uses the term fureur. It is used to characterize violent anger, but also anger that develops too quickly, without providing either the character or society an opportunity to defuse the passion. The infuriated duke of tale 70 who suspects his friend of disloyalty refuses to wait long for proof to the contrary:

avecques ung visaige furieux, luy dist: "Or choisyssez de deux choses l'une: ou de me dire celle que vous aymez plus que toutes, ou de vous en aller banny des terres où j'ay l'auctorité, à la charge que, si je vous y treuve huit jours passez, je vous feray mourir de cruelle mort." (486)

His pride stung, the friend also lets anger dictate a hasty response and both men thus fall into the spiteful duchess's hands.

Stories that conclude with a return to social harmony often show the community restricting a passion that individuals struggle to restrain on their own. It is the princess's dame d'honneur in tale 4 who succeeds in curbing her rage and her thirst for violent revenge. She does so by evoking the social condemnation that would be sure to follow a punishment perceived as immoderate. Once the princess fixes on a plan that will allow her both to express her anger in a socially accepted way and to acknowledge her self-worth, her passion loses its potential for violence and is replaced by the sleep of the innocent. In other stories it is spouses who intervene to maintain social stability (tales 44 and 59), but in each case the individual mediator represents a larger public judgment passed on acts inspired by anger. The characters share a sense of accountability to a greater community.

The words Marguerite chooses in order to depict anger suggest a set of criteria for judging the righteousness of anger, criteria whose limits are further explored in juxtaposed stories. By using narrative techniques as well as vocabulary, Marguerite constructs a more nuanced analysis than one that can be derived from isolated examples. Stories that treat anger tend to occur in pairs throughout the Heptaméron (tales 1 and 2, 3 and 4, 5 and 6, 21 and 22, 35 and 36, 51 and 52, 58 and 59). ${ }^{17}$ The reader thus experiences immediate

17. Although the different, surviving manuscripts and editions of the Heptaméron do not provide any single, definitive sequencing for Marguerite's tales, these tales are consistently paired together in most of the known manuscripts and are further linked by devis that serve as transitions between them. 
comparisons between male and female anger, violent anger followed by controlled anger, humorous outcomes of anger and tragic ones, anger that the devisants judge justifiable and anger they condemn. These groupings and the discussions that link them engage the devisants in developing and articulating a complex code of acceptable expressions of anger. ${ }^{18}$

Let us return to tales 36 and 37, the tales that Davis uses as evidence of Marguerite's openness to women's anger, in order to evaluate how this grouping further refines the patterns traced in the rest of the collection. Davis, too, is careful not to consider these tales in isolation and looks at the discussions that follow each. These particular tales, however, can be seen as forming an extended analysis of anger that incorporates a third tale (35) and the discussions that frame all three. Throughout this section, the devisants consider the relative harm of different passions and illustrate, by their own reactions, the place they accord to anger. The discussion begins after tale 34 with a philosophical debate provoked by Saffredent: "Et je treuve aussy bon, comme ilz font [...] de vaincre une passion vicieuse, mais une passion naturelle qui ne tend à nul mal, ceste victoire là me semble inutile" (308).

Hircan explores the question by addressing the emotion of pride through his account of a respected married woman who nonetheless develops a passion for the local priest. He chooses to narrate the dishonour that befalls the couple from a comic perspective. The wife propositions the priest in a letter that she plans to have delivered by a servant. Her husband, however, intercepts both the servant and the letter. He thus learns of his wife's intended infidelity in the presence of their page. Rather than act impulsively, the husband "dissimul[e] sa collere" (312) and concocts a plan whereby he will first disguise himself as the priest and then punish his wife with a beating. After a successful performance, he invites the priest to his home (under the pretense of concern over his wife's demonic ravings). The wife, confronted with the man she believes has rejected her amorous advances and physically assaulted her, flies into a rage ("une merveilleuse collere," 315) and tries to harm the priest. The husband, of

18. Representations of anger in seventeenth-century literature trace a different set of social codes and limits. See Roxanne Roy, L’Art de s'emporter. Colère et vengeance dans les nouvelles françaises (1661-1690) (Tübingen: Gunter Narr Verlag, 2007) and Margot Brink, "La colère dans le processus de la civilisation: transformations d'une passion héroïque dans la littérature du XVIIe siècle," Colère-force destructive et potentielle: lémotivité dans la littérature et le langage, ed. Lydia Bauer and Kristin Reinke (Berlin: Frank \& Timme, 2012), 127-44. 
course, is there to save the man of the church and to enjoy discreetly the end of his wife's illegitimate passion. Husband and wife remain together, reconciled thanks to the calculated outlet the husband found for his anger.

The devisants do not contest the "bon sens" that Hircan praises in the husband figure and seem to find nothing unusual in his way of venting anger or revenging his honour. But the story itself fuels an altercation between Parlamente and Ennasuitte whose divergent judgments on the wife hint of personal attacks on one another. Hircan invites Ennasuitte to tell the next tale in order to mollify her. Her story, told in anger, assumes a more serious tone, but follows a similar plot line to Hircan's: that of a cuckolded husband who successfully orchestrates his revenge. This time, however, the rival is exiled and the wife murdered. Even the servant, caught in the middle, fares worse; his own reputation and position are sacrificed in the name of discretion.

Although some form of anger obviously underlies the entire story, Ennasuitte never refers to the husband's emotion by name. The devisants can agree neither on the extent to which the man's reaction was physiological nor on his culpability. Tellingly, the terms furie and collere are both proposed. In typical fashion the discussion revolves around questions of honour. Parlamente extends the story to a larger social context by sarcastically remarking on the number of casualties this approach might entail should the husband's strategy be applied to all unfaithful wives. This time it is Hircan who is angered by the discussion, in particular by what he perceives as the self-righteousness of his wife. The devisants argue along gender lines, before Dagoucin promises to tell the next story in support of women.

In tale 37, he revisits the same elements in yet another configuration. Again there is a wronged spouse, intervening bystanders, and an act of violence. Dagoucin's offended party is a wife whose husband repeatedly commits adultery. She responds initially by succumbing to melancholy, but when her extended family reminds her of her duties to her household and children she tries to overcome her emotions and become a patient wife. Her patience, however, soon wears thin and she turns to a different emotion, converting melancholy into anger and then setting fire to the straw upon which her husband and his mistress lie. This tale splits the female devisants who cannot agree on an interpretation of the wife's response. Was she too angry or not angry enough? Did her anger not risk provoking the anger of her husband in retaliation? Again, 
the debate hinges on the degree of anger and on its manifestations, taking for granted that the woman could and should experience anger.

Although the devisants rarely come to any consensus, tales 35,36 , and 37 and the related discussions once again highlight honour, the dangers of containing a violent emotion, and the importance of social regulation in the assessment of anger. Men and women alternate in the role of the irate character with relative impunity. Neither sex manages to suppress anger completely. The expression of the emotion is presented, not as a shortcoming, but as a beneficial outlet for strong passions of all kinds (jealousy, melancholy, desire). When rage is suppressed it can turn lethal as in the case of the president in tale 36. Although its open expression can also have violent consequences, acknowledged anger proves less destructive than the emotions it displaces. The wife in tale 37 regains her sense of self-worth and stops neglecting the household economy once anger overcomes her melancholy. The lovesick wife of tale 35 replaces her adulterous passion with a purifying anger targeting the same priest. Offended spouses find relief in acting on the anger they feel. As Nomerfide concludes elsewhere, "je veoy que les folz [...] vivent plus longuement que les saiges, et n'y entendz que une raison, c'est qu'ilz ne dissimulent poinct leurs passions. S'ilz sont courroucez, ils frappent [...]" (304).

Although the tolerance of violence is more difficult for us to accept today, Parlamente and her companions viewed physical violence as less shocking than dishonour: "une femme de bien ne seroit poinct si marrie d'estre battue par collere que despriser par une qui ne la vault pas" (327). But violence is condoned only when it serves to strengthen a community and its fundamental values. As the result of individual madness or asocial desires, violence would simply be a threat. If the wife of Tours (the guilty spouse from tale 35) and the wife of Loué (the victimized, offended spouse in tale 37) are both allowed an anger that leads to physical violence, it is because their fire (literal and metaphorical) succeeds in cleansing them of more insidious passions that were causing them to neglect their social responsibilities.

The least controversial angry character, the husband of tale 35 , mitigates his violence in several ways. He does not beat his wife in the heat of his anger. Instead he gives himself time to choose an effective punishment and then assumes the role of the priest in order to enact it, thus separating even further the personal anger he initially felt from the beating he eventually gives his wife. Unlike the president from tale 36, the husband from tale 35 makes his 
servant complicit in the violence, worrying less about the page witnessing his dishonour than about treating him fairly. It is true that both husbands angrily threaten their servant, but the husband from the comic tale ultimately honours the servant's fidelity and his place in the household. In so doing he provides a rare example in the Heptaméron of community stability that includes a notion of the interdependency of the classes. The page's role as facilitator suggests that the revenge is not just that of a single, irate husband, but of a united male community. Moreover, the husband does not put an end to his marriage (or to his wife) because of a single offense, adopting the more socially tenable perspective Longarine thinks the Président should have chosen: "puisque sa grande collere estoit passée, elle eust vescu avec luy en femme de bien et n'en eust jamais esté memoire" (322).

The extent to which this man achieves distance from his selfish interests is reflected in his desire to laugh during his revenge scenario. His laughter is less an indication of sadism than of his ability to transcend his own sense of self-importance and move beyond his anger. The connection between self-love and anger is a clear subtext for this sequence of stories about the nature of passion. These two passions are intertwined from the very first story about the wife whose sense of invincibility makes her more vulnerable to Cupid's arrows through to Hircan's final reproach of the angry female devisants after tale 37: "vous n'aymez voz mariz que pour vous" (328).

At the level of the narration, too, laughter serves as an effective means of diffusing anger and countering its selfish nature. Already in day one, Longarine displays a similar understanding of laughter. When, in the devis following tale 8, Geburon reproaches her for provoking the ire of Hircan and Saffredent instead of making them laugh with her storytelling, she retorts thus: "Cest tout ung [...] mais qu'ilz ne viennent poinct à tirer les espées, leur collere ne fera que redoubler nostre rire" (56). Despite Longarine's allusion to drawn swords, the palliating effect of laughter is most efficacious in verbal, not physical, confrontations. Marguerite explores with equal attention these more everyday examples of anger and their connection to storytelling itself. The act of narrating angry men and women itself can anger the other devisants or can be wielded as an act of revenge: "je [...] donne [la parole] à Ennasuytte, pour la rapaiser contre ma femme. - 'Or, puis que je suis en mon rang, dist Ennasuyte, je n'espargneray homme ne femme, affin de faire tout esgal [...]'” (318). Among the devisants, too, anger is an expected response to an attack on one's 
honour. But in responding to these verbal challenges, it is equally important to respect limits and to be governed by the interests of the group. Thus Longarine is reproached for angering two companions with her storytelling and for threatening the cohesion of the community. To remedy the situation, she appeals to the group to relativize the offense and to restore harmony through laughter. None of the devisants is ever reproached for getting angry or for speaking sharply. According to the implicit rules of the group, offending others through storytelling is allowed if a balance of sorts is maintained. If women are shown to their disadvantage in one tale, the following tale should redeem them and vice versa. The anger elicited by a tale is to be calmed by the laughter induced by the next story. The alternating narration guarantees each a chance to right a perceived wrong by enacting a verbal revenge. In the sequence of tales from day four, Parlamente and Hircan become incensed by the reactions of the other and by the underlying beliefs each holds about the roles of the sexes. But through storytelling, their anger is expressed, their perspectives publicly acknowledged, and a reconciliation is made possible. Anger and its threat of social dissolution bring Hircan to a submissive stance that his wife, in turn, must reject. An equality of sorts is re-established.

Storytelling is, after all, not just a form of recreation but an integral part of regulating anger and revenge in a community, as Davis has shown with Fiction in the Archives. Angry characters, forced to justify their rage-inspired actions and to make these intelligible to a community turn to the creation of pardon tales. These stories will determine the community's verdict, as the duke in tale 70 understands: "toute la compaignye fut si estonnée que l'on pensoit que le duc fust hors du sens. Mais après qu'il eut parachevee ce qu'il vouloit, assembla dans la salle tous ses serviteurs et leur racompta l'honneste et piteuse histoire [...]" (496).

Ultimately, however, even communal interests cannot completely legitimate anger. Even though his anger has been deemed justifiable by his serviteurs, the murderous duke is still held accountable to a higher order of justice. The fallibility of social beings, pressured by honour and incapable of completely transcending selfish concerns, falls short of the Christian ideal, and the duke makes amends by retreating from the world: "et s'alla rendre religieux en l'abbaye où estoit enterrée sa femme et les deux amans" (497).

Contrition for more conventional, less violent forms of anger also leads to increasing self-abnegation. The devisants alternate the narration of stories, 
thus allowing each devisant to express his or her subjectivity for a limited time before returning to the collectivity that is the audience. The recreational storytelling, itself, takes place in tandem with Oisille's biblical readings which remind the devisants of the more exacting, Christian precepts for behaviour and further humble them.

Anger, then, has an important place in the Heptaméron, between social reality and social regulation, between a defense of self-worth and the abnegation of self. These tales and the reactions of the devisants call for anger to be contained in order to protect society, but they also make room for a just anger that "femmes de bien" of different social ranks can experience and display publicly. Without making an apology for all forms of anger, Marguerite depicts women and men as equally capable and culpable of this passion. An analysis of Marguerite's literary treatment of anger confirms Davis's characterization of the Heptaméron as a collection of stories that imagine a legitimate female anger. ${ }^{19}$ As such, Marguerite's work establishes a literary precedent for texts revalorizing women's passions and for women writing about women's passions. By situating anger in the specific context of sixteenth-century French society, Marguerite at once ennobles it by linking anger to the complex system of honour and retribution, and renders it banal by also illustrating its commonplace nature and affinity to self-importance. Her complex and gendered depiction of anger thus traces a psychological map of sixteenth-century French society that can be seen as anticipating another emotional mapping in the fictional prose of Madeleine de Scudéry a century later. ${ }^{20}$ Finally, Marguerite's collection of tales celebrates the myriad ways in which storytelling and passions intersect, thereby recalling the potential of literature for sounding out the human heart and for effecting social change.

19. Maria Zayas, for example, could follow Marguerite's model with her Novelas amorosas. In the introduction to her translation of these stories, H. Patsy Boyer describes Zayas as believing that women, like men, should "assume responsibility for their own honor" even when this involves violent revenge. See María de Zayas y Sotomayor, The Enchantments of Love: Amorous and Exemplary Novels, trans. H. Patsy Boyer (Berkeley: University of California Press, 1990), xvi.

20. On the political and literary significance of Scudéry, see Joan DeJean, Tender Geographies: Women and the Origins of the Novel in France (New York: Columbia University Press, 1991). On the socially contextualized, positive roles for women imagined in the fiction of Mme de Scudéry, see Anne E. Duggan, Salonnieres, Furies and Fairies: The Politics of Gender and Cultural Change in Absolutist France (Newark: University of Delaware Press, 2005). 
